\title{
The Factors of Teacher Leadership Behaviors on Sport Class
}

\author{
Pandit Isbianti \\ Departement of Educational Administration \\ Universitas Negeri Yogyakarta \\ Yogyakarta, Indonesia \\ panditisbianti@uny.ac.id
}

\begin{abstract}
School advanced is something important for every school. The one of many factors which influencing school advanced is teacher leadership. The success of teacher leadership may lead to school advanced. Therefore, the factors of teacher leadership need to be identified in order to know the supportive and obstructive factors. By awaring those factors, every school can optimize the supportive one and minimize the obstructive factors. To give more explanation about the factors of teacher leadership, the author was conducted a qualitative research that aimed to explore the teacher leadership based on appear phenomena. This research was conducted in sport class, which has different characteristic from regular class so that gave the new nuance to teacher leadership. This paper presents the factors of teacher leadership which is the one of the main result of the research. Those factors can be divided into internal and external factors. Internal factors of teacher leadership consisted of: teacher's skills, teacher's passion to develop themselves, teacher's commitment, and teacher's creativity. Meanwhile, external factors of teacher leadership include: teacher's task, the principal, senior teacher, the students, professional development opportunities, parents involvement and cost. In other words, this paper presents the contextual research results, which provide several factors of teacher leadership. This research result may be adopted especially in schools that have same characteristic as school in this research.
\end{abstract}

Keywords-teacher leadership behaviors, factors of teacher leadership, sport class.

\section{INTRODUCTION}

Along with the knowledge and technology development, the advancement and public demand are two things that can not be avoided. Education is one aspect that can not be separated from those things. It means that education must adapt to the advancement and public demands. This situation needs to be realized by every education institution including school to respond the advancement and public demands in appropriate way. Creating an advanced school is one way to respond those situations. The advanced school can be embodied by doing quality learning activities. Meanwhile, how teacher perform their role in teacher leadership is the key of quality teaching activities. All these means that teacher leadership is an important factor in embodying advanced school [1]; [2]; [3]. The importance of teacher leadership needs to be realized by every teacher, whether teaching in regular class or special class with specific characteristics such as sports class. Recently, research on teacher leadership has been conducted.
However, these studies were conducted only on regular class, in which the results have the same characteristics each other. Based on the fact, the author try to conduct research on teacher leadership in sport class. By conducting research in sport class, Author called out for the new findings about teacher leadership based on the phenomenon that occured inside which may be different from regular class. It means that this research provides the contextual results that may give the new nuance for educational world. This research was conducted specially to explore the factors that had influenced teacher leadership in sport class. Based on the result of this study, the factors that affect the teacher leadership can be divided into two, firstly internal factors and secondly external factors. Internal factors of teacher leadership in a sport class consisted of: teacher's skills, teacher's passion to develop themselves, teacher's commitment, and teacher's creativity. Meanwhile, external factors of teacher leadership in sport class include: teacher's task/duty, the principal, the senior teacher, the student, professional development opportunities, teacher's creativity, parent's involvement, and cost.

\section{METHOD}

The study about the factors of teacher leadership behavior in sport class of public senior high school I of Sewon Bantul conducted by using qualitative research with phenomenology approach, to describe several individual's phenomenoa [4]. This study was conducted to capture and describe the factors that influence teachers while implementing various teacher leadership behaviors based on the emergence of phenomena. This study was conducted in Public senior high school I of Sewon, Bantul District, Yogyakarta, Indonesia, which have been hold the special program such as the sport class program. The public senior high school I of Sewon is one of several schools which success in holding sport class program, so that this study conduct in this school. The subject of this study was the teacher who has been teach in sport class. Meanwhile, data in this study were collected by in-depth interview and were analyzed by using a Miles and Huberman model which consisted of data reduction, data display, and conclusion drawing / verification [5]. 


\section{RESULTS AND DISCUSSION}

The factors of teacher leadership behaviors in public senior high school I of Sewon can be divided into internal and external factors. Internal factor is the factor which comes from teacher it self. Meanwhile, external factor is the factor that emerge from outside teacher. Internal Factors of Teacher Leadership Behaviors

Teacher's Skills

According to the research result, teacher's skills become one of the most influential factors for teacher leadership especially in designing curriculum. All these means that teacher's skills are the factors that determine the success of curriculum that had designed by teachers. In sport class of public senior high school I of Sewon, teacher must ready to face uncertain condition while teachers want to create the conducive class. In this case, conducive class becomes the expected situation. To create the conducive class, teacher needs to determine what strategy should be applied. When teacher apply the learning strategy as a part of designing curriculum, teacher may build learning environment. The conducive learning environment associated with student development in general and student compliance in specific [6]. All these means that teacher's skills are needed to create these expected curriculum.

\section{Teacher's Passion to Develop Their Professionalism}

Self-development is important for teachers. The importance of self-development for teachers is not solely due to obligations, but it is more tend to a necessity. The need for self-development is a driving force so that teachers have a desire to develop themselves. Self-development is part of professional development activities, while professional development is one of form of teacher leadership behaviors. Professional development activities in public senior high school I of Sewon can be carried out in many ways, such as: continuing formal education, join the training program, workshops, seminars, and join the professional associations. The importance of teacher professional development is in line with [7]: "Teachers need to grow and develop continuously in the teaching profession." Thus, the teacher professional development as a part of teacher leadership always need to be improved and carried out in a sustainable manner. Ediger and Rao's statement is reinforced by [8] who state that teacher education can be a power central for qualified education in the future. Teacher professional development activity also expected to improve the learning effectiveness and partnership [9].

\section{Teacher's Commitment}

Maintaining a successful culture is one of form of teacher leadership. According to the research result, teachers of sport class in public senior high school I of Sewon Bantul had maintained successful culture by giving motivation to the students and encouraging students to be consistent during doing their role as sport class students. In fact, both giving motivation and encouragement to sport class students are strongly influenced by teacher commitment. Teachers who have a commitment will play their leadership role as working totally. All these means that teacher's commitment highly influencing sport class teachers during practicing teacher leadership.

Teacher's Creativity

Teacher's creativity is one of many factors that also influence teacher leadership behaviors in sport class of public senior high school I of Sewon Bantul. Teacher leadership behavior that influenced by teacher's creativity is collaboration with school library. Collaboration with school library called out as cross-role collaboration [10]. Doing cross role collaboration means involving other unit (except teacher) to work together creating the good quality learning. This collaboration needs teacher's creativity to generate any ideas during create learning activites which involving school library. It means that teacher's creativity is important factor that may lead to success cross-role collaboration. The External Factors of Teacher Leadership Behaviors

Teacher's Task

According to [11] teacher's tasks include: teaching, educating, guiding, training, directing, evaluating, and assessing. By this regulation, teacher may do their tasks. Based on research result that had conducted by author, teacher's tasks become the prominent factor that influence teacher leadership behaviors. Most of teacher leadership behaviors in sport class of public senior high school I of Sewon influenced by teacher's task. All these means that sport class teachers in public senior high school I of Sewon, Bantul had internalized their tasks as the consequences of teacher's obligation. By internalizing their tasks, sport class teachers do understand what should they do during working as teacher.

Principal

The principal is one of the factors that influence teacher leadership behavior in sport class of public senior high school I of Sewon Bantul. As a factor of teacher leadership behaviors, principal collaborate with teachers to create the good atmosphere that may increase student achievement and learning. By doing collaboration, principal and teacher had worked and built meaning together. What principal has done had felt by sport class teacher in public senior high school I of Sewon Bantul as a real support and something useful. This fact is in line with [12] who stated: "principals who were reported as engaging in collaborative leadership were seen as better equipped to both understand and support the leadership of others in the school." Furthermore, factors who came from principal consisted of; The principal's leadership style, the principal's psychological, the principal's idealism, and the principal's job. All those factors indicate that principal as a leader can influence subordinate activities by promoting desirable behavior and restricting undersirable behavior [6]. Those factors can be described in detail as follows.

\section{(a)Principal's Leadership Style}

Public senior high school I of Sewon Bantul had held the meeting regularly every once a month. The school community usually do coordination by using this meeting. The meeting which held regularly by public senior high 
school I of Sewon Bantul belongs to teacher leadership behavior especially collaboration because in the meeting, the principal opened up to receive all inputs, ideas and suggestions, as well as opening up to listen any complaints and problems faced by teachers and also employees. What The principal do in the meeting indicates that the principal has a democratic leadership style. This democratic leadership style may encourage teachers to participate actively, speak loudly and think critically in those meeting which may lead to raise collaboration.

\section{(b) Principal's Psychological}

Giving support to teacher is one of part of principal's tasks that can be done by doing communication formally and informally. The success of formal and informal communication influenced by principal's psychological. In addition, the principal's psychological also influence the principal's mood. The meeting which held by Public senior high school I of Sewon regularly belongs to formal communication. Meanwhile, informal communication belongs to unplanned communication which may occured incidentally. In brief, principal's mood will influence the quality of communication.

\section{(c) Principal's Idealism}

Idealism is a perfection standard. As a result of this research, principal's idealism is one of factors that influence teacher leadership behaviors. This principal's idealism tends to effort to create good learning activity. The success of learning activity can be achieved by making a good preparation. All these means that principal of public senior high school I of sewon bantul had demanded every teacher in his school to make a good preparation such as lesson plan and syllabus in order to create a quality learning. What teachers do to prepare the lesson belong to teacher leadership behavior that related to designing curriculum. In this context, curriculum defined as a good learning situation. In brief, principal's idealism may raise teacher leadership behavior.

(d) The Principal's Duty

Education in school identical with learning of sciences and knowledges. Even, educational institutions (school) become the place where sciences and knowledges born and develop. It indicates that sciences and knowledges are always develop time after time. This development should be adjusted by teachers. To adjust this development, teachers should develop their professionalism. All these means that developing professionalism is a part of teacher's obligation. Developing Professionalism belongs to teacher leadership behavior which related to learning activity. Supporting teacher to develop their professionalism belongs to principal's duty. In sport class of public senior high school I of sewon, principal support the teachers to develop them selves by giving information about the chance of professional development, giving them opportunities to join the professional development activities, and giving permission for teacher who wants to continue their formal study. Those principal's support may lead sport class teachers in public senior high school I of Sewon to develop them selves. In brief, principal's duty belongs to the factor of teacher leadership behavior. In other word, the role of principal's duty may affect the success of teacher leadership [13]. One of the facts about this principal's influence was demonstrated by Barth [2] which revealed: The principal has a disproportionate influence on teacher leadership. Even though some principals find it risky to share leadership, many do find ways to inspire a culture of teacher Leadership within their schools. This piece offers actions for how the principals can support and influence the success of teacher leaders. It means that giving support to teachers is a principal's choise. The greater support gives to teacher, the more determining the success of teacher leadership. The principal's support for teacher leadership can be done by (10) building the principal's knowledge of teacher leadership and (4) increasing the interaction between the principal and the teacher [2].

Students

Taking some actions in every learning activity become the teacher's daily task. Every learning activity always involve students as the object. All these means that teacher always face and meet the students in every learning activity. This fact indicates that students become a part of learning activities, and also influence the success and failure of those learning activities. Every action which taken in every learning activities is a form of teacher leadership behaviors. It means that students belong to the factor that influence teacher leadership behaviors. The factors which come from students consisted of; student's characteristics, student's feeling, and student's reading interest. Those factors can be described as follows:

\section{(a) The Student's characteristics}

Every student bring their own character. It means that students in sport class of public senior high school I of sewon Bantul have the various characteristics that different one each other. Every student's characteristic can be seen from student's behavior. Every student's behavior will influence teacher to take a professional skill. Meanwhile, showing or taking professional skill is the one of form of teacher leadership behaviors it self. All these means that student's characteristics had influenced teacher leadership behaviors.

\section{(b) The Student's Feeling}

Student's feeling is something that raise from student as a respon of something. Student's feeling can be seen from student's attitudes and deeds. Not really different from student's characteristics, student's feelings also lead the teacher to take any specific actions. All these means that Student's feelings also become the factor which influence teacher leadership behaviors. By understanding student's feeling, may help teacher to determine the appropriate teacher leadership behaviors that is in line with student's need. The form of teacher leadership behaviors that influenced by student's feeling is using professional expertise. Deal with using professional expertise, teacher may use the learning approach that appropriate with student's feeling. The learning approach for student who's 
sad surely different from learning approach for student who's happy. By using different learning approach, teacher had used his/her sensitivity to student's needs. Teachers are charismatic leader when they use sensitivity to their student's needs. This findings is in line with Conger and Kanungo [6] who said: "charismatic leaders use their sensitivity to the abilities and needs of their followers and to the resources and constraints in the environment. (c) The Student's Reading Interest

The one of the research result on teacher leadership in sport class of public senior high school I of Sewon Bantul that had been done shows that sport class student's reading interest still need to improved. This phenomenon influences teachers to do cross-role collaboration, in which done with school libraries. This cross-role collaboration is expected to improve sport class students' reading interest. Senior Teacher

The other factor that also influences teacher leadership behavior is senior teacher, that associated with team teaching. Team teaching is one of form of teacher leadership behaviors. As a factor of teacher leadership behaviors, senior teacher can be a supporter or a barrier. In sport class of public senior high school I of Sewon Bantul, senior teachers become supporter when they have skill, have openness, and provide support. Conversely, senior teachers may become barrier when they're incompetent and don't want to share their knowledges. To avoid the raise of barrier factors, teacher must always develop their professionalism. By developing professionalism, teacher's skills may improved. This improvement may change teacher's mindset and lead the teachers to share their knowledges and experiences to junior teachers. Sharing of knowledges and experiences is the one of form of teacher leadership behaviors. All these means that junior teachers can take many advantages and learn many things from senior teachers. In brief, senior teachers also determine the success and failure of teacher leadership.

Professional Development Opportunities

Professional development opportunities are one of factors that also influence teacher leadership behaviors. The more opportunities to develop, the more teachers become professional. The opportunity of professional development according to [13] belongs to material resources. The research result shows that teacher's opprtunity to develop their professionalism consisted of :

(a) The Time Availability

Time availability can be a booster of professional development. The more time available, the more professional development activities can be done. Conversely, the less time time available, the more minimal professional development activities can be done. It means that the minimum available time can be an obstacle for teachers to conduct professional development activities, which automatically also hampers teacher leadership. In public senior high school I of Sewon Bantul, most of teachers join the professional development activities like workshop, seminar, and training. Even, two of teachers in public senior high school I of Sewon Bantul had join the post graduate to continue their formal study. Only bit of them do not join the professional development activities because they must do other duties at the same time. All these means that the time avaibility becomes the important factor for teacher to join the professional development activities.

(b) Providing Opportunities for Teachers to Do Professional Development Activities

Providing opportunities for teacher means giving support and permission for every teacher who wants to do the professional development activities. Support and permission usually given by the principal. However, in the team teaching context, support and permission from senior teacher also needed.

Based on the research result, the principal in public senior high school I of Sewon Bantul had given support and permission to the teachers to do professional development activities. Professional development for teachers is a teacher's obligation in one side and teacher's right in other side. As an obligation, the professional development should be realized by teachers so that the teachers can develop them selves without compulsion. As a right, teacher's desire to develop their professionlism should be supported and facilitated by principal so that the teachers can actualize them selves. Beside giving suport and permission to the teachers, the principal in public senior high school I of Sewon Bantul also gave information about the chance of teacher professional development. This information may be expected to raise the teacher's enthusiasm and also to make the teachers know about the existance of teacher professional development program. All these means that principal has a important role in teacher professional development [3]. The principal's role is not only as an instructional leader, but also as a developer community leader in school he leads. As the developer of community leaders, it is only proper if the principals provide an opportunity for teachers to develop themselves. Teacher professional development activity also expected to improve the learning effectiveness and partnership [9]. In addition, a good principal must direct teacher professional development as an investment. By this investment, the institution (school) will be going strong.

(c) Institution Duty

Based on research result, the initiative to join or do professional development activities may be comes from the teacher it self and maybe comes from the other (outside of teacher). Institution duty belongs to comes from outside of teacher. The real form of institution duty in public senior high school I of Sewon Bantul is delegating teacher to join the professional development program. The more often the institution (school) or principal delegates the teachers to join the professional development program, the more teachers getting skilled.

\section{Parent Involvement}

The other factor that influence teacher leadership behaviors is parent involvement. In Public senior high 
school I of Sewon Bantul, teachers involve the student's parent in using professional expertise. In this case, parents help the teachers to control their children in order to do every school task that given to the students. Furthermore, parents will put their sign in every student's task as a proof that student had done the task at home (not in school by cheating homework with friends). By involving parents as a form of teacher leadership behavior, teacher may use their professional expertise easier and student may improve their achievement. All these means that parents involvement is the one of factor which influence teacher leadership.

\section{Cost}

Cost is the amount of money spent for certain purposes. As previously mentioned factors, cost is also a factor affecting teacher leadership. According to [13], costs belongs to material factors. The teacher leadership behaviors that are influenced by this factors divided into two. Those are professional development activities such as training, seminars, or workshops, and collaboration. In this context, collaboration tend to learning program which done by extra money. In other word, to do those activity, money availability is required.

\section{REFERENCES}

[1] Danielson, C. (2006). Teacher leadership that strengthens professional practice. Virgina USA: ASCD Publication.

[2] National Comprehensive Center for Teacher Quality. (2007). Enhancing teacher leadership. Washington, DC: A collaborative effort of education commission of the States, ETS, Learning Point Associates, and Vanderbilt University.

[3] York-Barr, J. \& Duke, K. (Autumn 2004). What do we know about teacher leadership? Findings from two decades of scholarship. Review of Educational Research. 74 (3), 255-316.

[4] Cresswell, J.W. (2007). Qualitative inquiry \& research designchoosing among five approaches. California: Sage Publications.

[5] Milles, M.B. \& Huberman, M.A. (2007). Qualitative data analysis - the reference of new methods. (a translation work). Jakarta: UI press.

[6] Goodboy, A.K. \& Bolkan, San (2011). Leadership in the college classroom: the use of charismatic leadership ad a deterrent to student resistance strategies. Journal of Classroom interaction . 46 (2), 4-10.

\section{CONCLUSION}

The study on factors of teacher leadership behaviour was reported. The factors of teacher leadership behaviors is an important thing, which may leads the successful and unsuccessful of teacher leadership behaviors. The results of this study are contextual so they can not be applied to schools with different characteristics than those in the study. Nevertheless, the results of this study can serve as a reference or benchmark for schools that have similar characteristics. Considering the importance of factors of teacher leadership behaviors, continuous study about the contribution of each factor need to do in the future. The exploration about contribution of each factor is important to show the most influencing factor that may lead to the success and unsuccess of teacher leadership. All these means that every principal and every teacher can take the appropriate way to strengthen factors with positive impact and to diminish factors with negative impact. By getting the new findings in the next study, the knowledge about teacher leadership will getting complete and rich.

[7] Ediger, M. \& Rao, D.B. (2010). Effective Schooling. New Delhi: Mehra Offset Press.

[8] Ganihar, N.N. \& Nayak, V.S. (2007). Human resource development and teacher education. New Delhi: Discovery publishing house.

[9] Rutherford, C. (2006). Teacher leadership and organizational structure-The implications of restructured leadership in an Edison school Educational. Change. 7. 59-76.

[10] Collay, M. (2011). Everyday teacher leadership- taking action where you are. USA: Jossey Bass.

[11] Indonesia Government regulation about teacher, number 74 year 2008.

[12] Thornton, H.J. (2010). Excellent teachers leading the way: How to cultivate teacher leadership. Middle School Journal. 41 (4), 36-43.

[13] Gigante, N.A. \& Firestone, W.A. (2007). Administrative support and teacher leadership in school implementing reform. Educational Administrations, 46, 302-331. 